\title{
Evaluation of Residual Stresses after Irregular Interrupted Machining
}

\author{
Sarka MALOTOVA, Robert CEP, Tomas ZLAMAL, Petr MOHYLA, Andrej CZÁN, Aco ANTIĆ, Igor BUDAK, Lobonţiu MIRCEA
}

\begin{abstract}
Residual stress occurs in many machined components and parts. Over time, several methods have been developed for the investigation of residual stress in the material - destructive and non-destructive. This article deals with the evaluation and comparison of residual stress in the material when machining steel $\mathrm{C} 45$ and $11 \mathrm{CrMo9}$ 10, when the tool enters into the cut and stands out in conditions of an interrupted cut. A non-destructive method, based on X-Ray diffraction, was applied to evaluate the residual stress. The points were measured on the last machined slat by using interrupted cut simulator. An irregular interrupted cut was achieved by gradually machining 4 , 3, 2 and 1 slat. The experiments were realized in co-operation with the Faculty of Mechanical Engineering, VSB - Technical University of Ostrava, Czech Republic and the Faculty of Mechanical Engineering, the University of Žilina, Slovakia.
\end{abstract}

Keywords: interrupted cut; machining; residual stress; X-Ray diffraction

\section{INTRODUCTION}

The properties of materials and components, their fatigue life, dimensional stability, susceptibility to corrosion, etc. may be influenced by residual stress. This undesirable effect causes expenses to repair and renovation of parts. Analysis of residual stress is very important $[1,2]$. Manufacturing process (machining, forming, welding, etc.) is a common cause of stress in material, stresses can occur during operation. In the area of welding, the origin of residual stress is the conditioned solidification of weld metal and the cooling down to ambient temperature. At this moment, uneven distribution of heat occurs. [3, 4]

The basic mechanisms of the formation of residual stress are uneven plastic deformation, thermal expansivity during uneven heating or cooling down, structural change and chemical processes. The residual stress is classified as stress: type I - macroscopic, type II - microscopic, type III - submicroscopic. The evaluated residual stresses may be compressive $(-)$ or tensile $(+)$. [5, 6, 7]

The selection of the parameters of the turning process carries out irrespective of the residual stress. It is well known that the presence of tensile stress in the surface may influence the functional properties of the component. The mechanical properties of the material have an influence on the size and type of residual stress. The aim is to suitably arrange cutting conditions for optimal distribution of residual stress in the entire volume of the material, preferably to zero values. $[8,9,10]$

The measurement and evaluation of residual stress may often be problematic because of the poor accessibility of place. The destructive form is not always acceptable for partial or total destruction of the sample. Using the nondestructive method based on roentgen diffraction (X-ray) assures an undamaged material surface and accurate result of stress. In comparison with other non-destructive methods (neutron, ultrasonic) X-ray has the advantages of simplicity of evaluation and variability of the measured area. A disadvantage of this method can be time demands. $[6,11]$

\section{SPECIFICATION OF EXPERIMENT CONDITIONS}

The measured semi-finished products were slats, which were machined on an interrupted cut simulator [12].
To achieve irregular interrupted cuts, slats were gradually removed from the simulator. Specifically, Adam Janásek's dissertation thesis addresses this problem - Experimental Influence Verification of Thermal and Mechanical Stresses on Edge Status at Irregular Interrupted Cutting [9].

The slats were machined under the following conditions: cutting speed $v_{\mathrm{c}}=204 \mathrm{~m} / \mathrm{min}$; cutting depth $a_{\mathrm{p}}=1 \mathrm{~mm}$; feed rate $f=0,11 ; 0,20$ and $0,32 \mathrm{~mm}$ of cemented carbide tool, trademark CNMG 120412E-R (6630). Geometry of the cutting tool is displayed in Tab. 1.

Table 1 Geometry of cutting tool [13

\begin{tabular}{|c|c|}
\hline \multicolumn{2}{|c|}{ Geometry of cutting tool } \\
\hline$\kappa_{\mathrm{r}}$ & $95^{\circ}$ \\
\hline$\psi$ & $-5^{\circ}$ \\
\hline$\gamma_{\mathrm{o}}$ & $-6^{\circ}$ \\
\hline$\lambda_{\mathrm{s}}$ & $-6^{\circ}$ \\
\hline$\varepsilon_{\mathrm{r}}$ & $80^{\circ}$ \\
\hline
\end{tabular}

Machined length was $L=25 \mathrm{~mm}$ for every combination of cutting parameters. One slat was always removed from the simulator after machining the material with the highest value of feed rate. The last slat, machined throughout the length, was used for measurement and evaluation of residual stress. Dimensions of each slat were $(48 \times 60 \times 600) \mathrm{mm}$.

The machined material was two pieces of steel with different properties. Steel C45 - unalloyed steel suitable for heat treatment is used for manufacturing fewer strain pieces. The second material, steel $11 \mathrm{CrMo} 9-10$ is a heatproof material used in the energy industry.

\subsection{Measurement of the Residual Stress}

The main parameter of measurement was the value of normal stress. The measurement of residual stress in the material was realized in the laboratory of the Department of Machining and Manufacturing Technologies at the University of Žilina in Žilina, Slovakia. Proto iXRD is a portable device working on the principle of X-ray diffraction - non - destructive method. This method is one of the most suitable in the field of machining. This device is able to measure and evaluate stress in all crystalline materials. The evaluation of the residual stress is in absolute physical unit mega Pascal (MPa). [13, 14] 


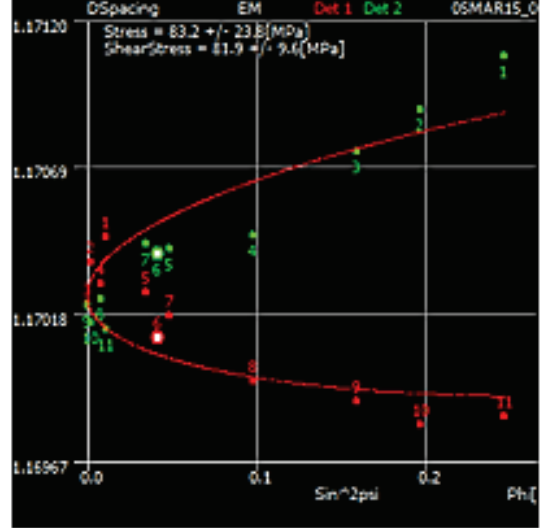

\section{PARAMETERS}

Mrterial :STEEL - FERRITIC (Cr_Ka)(BCC, hlll-211)

Twbe: Cr K-Alpha

Worelength: 2.291

EV.20.00;

Beta Osc:3.00; Phi Osc.0.00; $X$ Osc. $0.00 ; F$ Osc.0.00;

Exp. time: $\quad 1.20 \quad 1.20$

Nr of exp: $\quad 20 \quad 20$

Aperture: 1

Filters :

Background static fit

LeftStartPixel : $99 \quad 44$

RigitstartPicel: $363 \quad 307$

ROI Lef: $\quad 85 \quad 41$

Conuments:

Figure 1 The evaluation of residual stress

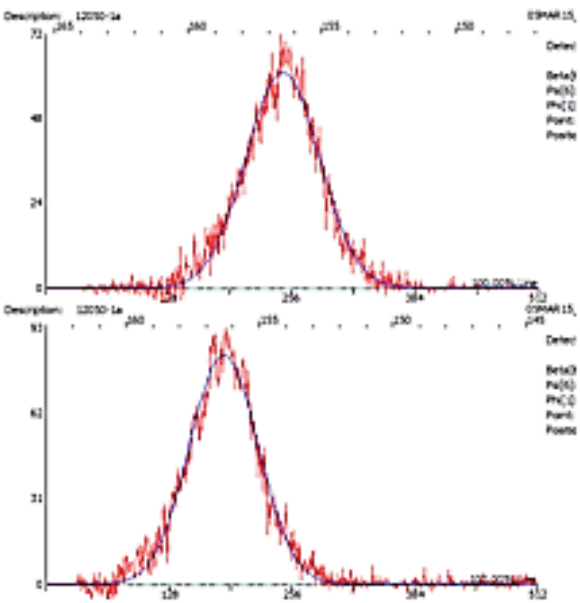

Linits: $\mathrm{MPa}$

Broge

Peak Location : Ganssian $100 \%$

Gain Correction: $\mathrm{P} / \mathrm{G}(\mathrm{s})$

Peak Shif: $\quad$ Absolute Peal:

(1/2)S2:5.92 E-6 [1/MPa] $-51: 1.28 \mathrm{E}-6[1 / \mathrm{MPa}]$

$D$ Spacing (Angstroms): $\quad 1.1702087$

LPA Correction: YES

Psi Zero Assignent (Pixel) .248.16 183.25

$\begin{array}{lll}\text { Left Stop Pixel : } & 109 & 54 \\ \text { Right Stop Pixel : } & 373 & 317 \\ \text { ROI Right : } \quad 392 & 339\end{array}$

Figure 2 Second part of evaluation protoco

A chrome tube to measure stress was selected on the basis of the measured materials. The sample "slat" was placed vertically below the collimator. The X-ray penetrates to a depth of $13 \mu \mathrm{m}$. Depending on the character of the residual stress, the X-ray diffracts in a cone- shape and is caught by the detectors. The X-ray is emitted at several head tilts in the range from $-30^{\circ}$ to $+30^{\circ}$. An evaluated protocol is shown in Fig. 1 and 2.
During the evaluation of one point, there were about ten measurements with the tilt-ray tube. The software XrdWin records signals and converts them into Gauss's curves. The Proto iXRD is shown in Fig. 3.

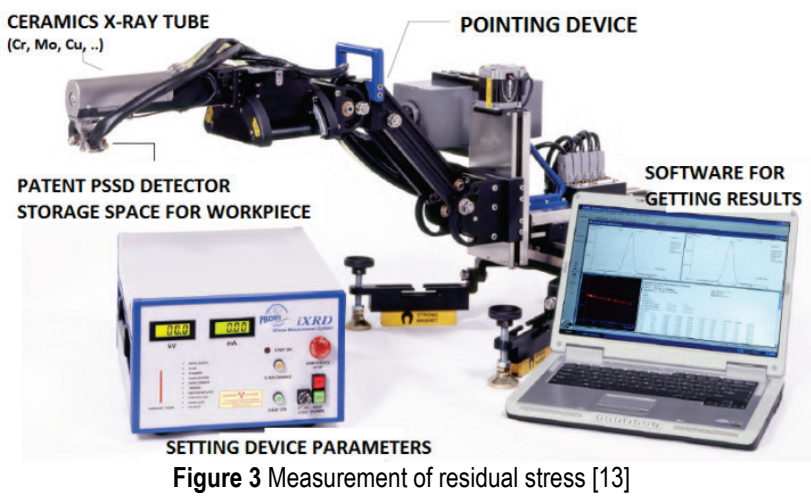

\section{RESULTS OF RESIDUAL STRESS}

The residual stress was measured for both materials for all examples at two points - the input tool to cut and the output from it. (Fig. 4). The values of stress in the tables are in mega Pascal units (MPa).

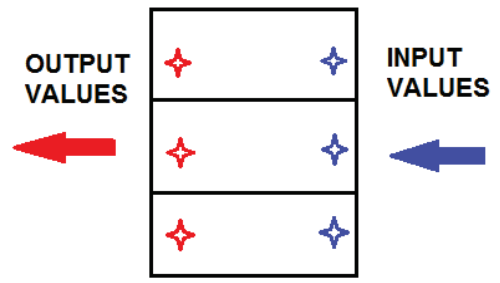

Figure 4 Distribution of points

\subsection{Measured Results of Residual Stress for Steel C45}

Tab. 2 shows values of the residual stress for steel C45. The table is separated into the number of slats in the simulator and the size of the feed rate. You can see the values for the input and output tool to cut.

Table 2 Measured values stresses for steel C45

\begin{tabular}{|c|c|c|c|}
\hline Stress $\sigma(\mathrm{MPa})$ & \multicolumn{3}{|c|}{4 SLATS } \\
\hline Feed rate $(\mathrm{mm})$ & 0,11 & 0,20 & 0,32 \\
\hline Input & $20,2 \pm 8,2$ & $109,2 \pm 26,3$ & $207,9 \pm 28,4$ \\
\hline \multirow[t]{2}{*}{ Output } & $1,6 \pm 7,9$ & $75,6 \pm 22,9$ & $157,4 \pm 25,5$ \\
\hline & \multicolumn{3}{|c|}{3 SLATS } \\
\hline Feed rate $(\mathrm{mm})$ & 0,11 & 0,20 & 0,32 \\
\hline Input & $70,9 \pm 22,7$ & $120,9 \pm 12,4$ & $136,1 \pm 17,1$ \\
\hline \multirow[t]{2}{*}{ Output } & $52,1 \pm 21,9$ & $99,4 \pm 11,8$ & $111,3 \pm 17,9$ \\
\hline & 2 SLATS & & \\
\hline Feed rate $(\mathrm{mm})$ & 0,11 & 0,20 & 0,32 \\
\hline Input & $56,2 \pm 17,0$ & $164,3 \pm 22,6$ & $199,0 \pm 21,0$ \\
\hline \multirow[t]{2}{*}{ Output } & $26,7 \pm 16,2$ & $149,4 \pm 21,9$ & $210,4 \pm 22,1$ \\
\hline & \multicolumn{3}{|c|}{1 SLAT } \\
\hline Feed rate $(\mathrm{mm})$ & 0,11 & 0,20 & 0,32 \\
\hline Input & $-116,2 \pm 12,9$ & $52,0 \pm 14,6$ & $138,0 \pm 23,3$ \\
\hline Output & $-89,4 \pm 11,0$ & $31,9 \pm 13,9$ & $113,2 \pm 22,8$ \\
\hline
\end{tabular}

The following graph (Fig. 5 and 6) summary compares the feed rate with stress for individual fixing (4, 3, 2 and 1 slat) for the input and output tool's values. The graph shows the stress increases proportionally to increasing of feed rate value. We can conclude that an irregular interrupted cut has an influence on the introduced stress. 
The highest value appears at the feed rate of $0.32 \mathrm{~mm}$ at an irregular interrupted cut. The compressive stress was measured in the presence of one slat in simulator, the feed rate was $0.11 \mathrm{~mm}$. Machining with one fix slat, feed rate $0.11 \mathrm{~mm}$ stresses interfere in negative numbers compressive stress. The measured value was $-116.2 \mathrm{MPa}$ The regular interrupted cut with the lowest feed rate value of stress approximates zero value.

The graph (Fig. 6) illustrates the comparison of the influence of the feed rate with normal stress for individual fixing for OUTPUT values. When the value of the feed rate is increased, the values of stress increase. The results of the output data are similar in character to the input data. The highest value of stress appears with the feed rate of 0.32 $\mathrm{mm}$ irregular interrupted cut (2 slats). The irregular interrupted cut with the feed rate of $0.11 \mathrm{~mm}$ able to presence negative numbers. The stress of the feed rate of $0.32 \mathrm{~mm}$ with 3 and 1 slat in simulator had a very similar character.
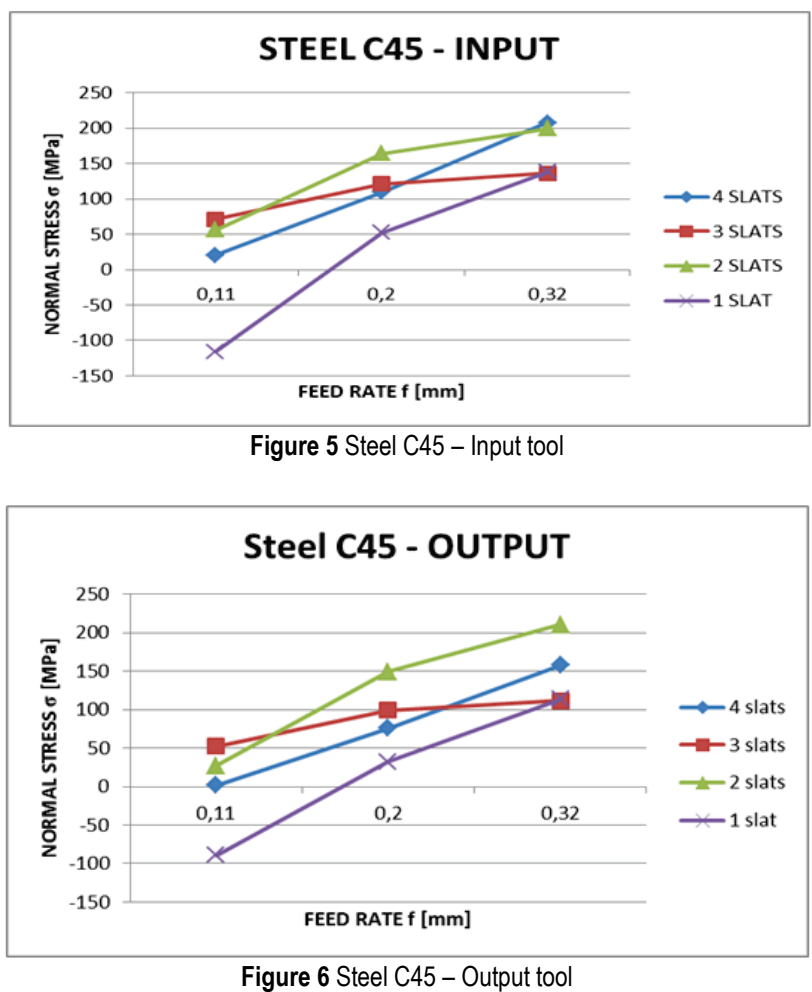

\subsection{Measuring Results of Residual Stress for Steel 11CrMo9-10}

Measured values of residual stress for material $11 \mathrm{CrMo} 9-10$ are stated in Tab.3 and graphically represented (Fig. 7 and 8).

The graph (Fig. 7) describes the influence of the feed rate on the normal stress for the individual fixing input values. This graph shows that when the feed rate increases, the amount of residual stress does not always increase. This graph (Fig. 6) illustrates the influence of the feed rate on the stress for the individual clamping of input values. For machining of steel $11 \mathrm{CrMo} 9-10$ it does not apply that the increasing values of feed rate have an influence to increasing of stress. We can see in conditions of the feed rate of $0.2 \mathrm{~mm}$ an increase of the stress during regular interrupted cut. In condition irregular interrupted cut when three slats were fixed in simulator for the feed rate of 0.2 $\mathrm{mm}$ stress decreases. For the feed rate of $0.32 \mathrm{~mm}$ the value of the stress was the highest, 233,2 MPa. Again, there was the introduction of the compressive stress for 2 slats of the feed rate of $0,11 \mathrm{~mm}(-89,4 \mathrm{MPa})$.

Table 3 Measured values of stress for steel 11CrMo9-10

\begin{tabular}{|l|c|c|c|}
\hline \multicolumn{1}{|c|}{ Stress $\sigma(\mathrm{MPa})$} & \multicolumn{3}{c|}{ 4 SLATS } \\
\hline Feed rate $(\mathrm{mm})$ & 0,11 & 0,20 & 0,32 \\
\hline Input & $39,7 \pm 18,9$ & $157,7 \pm 21,7$ & $163,5 \pm 24,7$ \\
\hline Output & $15,2 \pm 18,3$ & $161,9 \pm 27,0$ & $225,8 \pm 21,1$ \\
\hline & \multicolumn{3}{|c|}{3 SLATS } \\
\hline Feed rate $(\mathrm{mm})$ & 0,11 & 0,20 & 0,32 \\
\hline Input & $142,7 \pm 17,4$ & $90,3 \pm 22,7$ & $233,2 \pm 28,2$ \\
\hline Output & $130,6 \pm 25,4$ & $105,6 \pm 27,2$ & $305,6 \pm 25,5$ \\
\hline & 2 SLATS & 0,20 & 0,32 \\
\hline Feed rate $(\mathrm{mm})$ & 0,11 & \multicolumn{4}{|c|}{1 SLAT } \\
\hline Input & $-89,4 \pm 24,5$ & $24,2 \pm 21,0$ & $-89,4 \pm 24,5$ \\
\hline Output & $-79,3 \pm 20,6$ & $38,1 \pm 25,4$ & $-79,3 \pm 20,6$ \\
\hline & \multicolumn{4}{|c|}{0,20} & 0,32 \\
\hline Feed rate $(\mathrm{mm})$ & 0,11 & $90,5 \pm 34,4$ & $63,7 \pm 19,3$ \\
\hline Input & $54,8 \pm 17,5$ & $102,9 \pm 31,9$ & $142,9 \pm 21,7$ \\
\hline Output & $41,1 \pm 20,3$ & \multicolumn{3}{|c|}{}
\end{tabular}

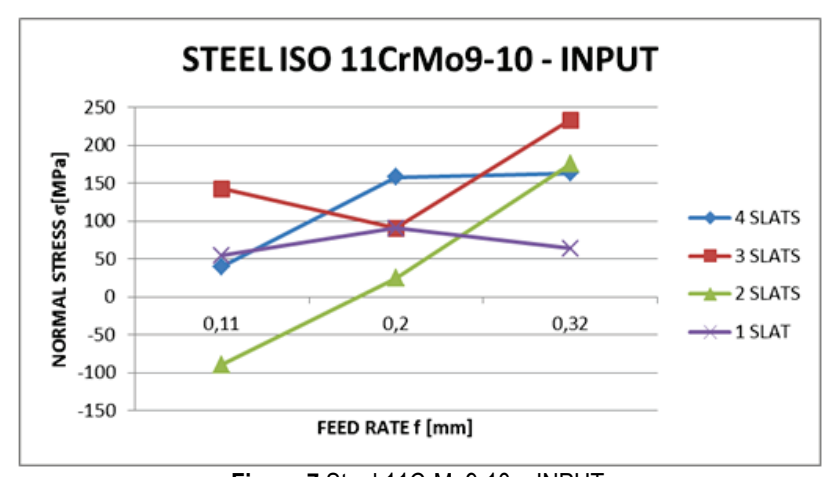

Figure 7 Steel 11CrMo9-10 - INPUT

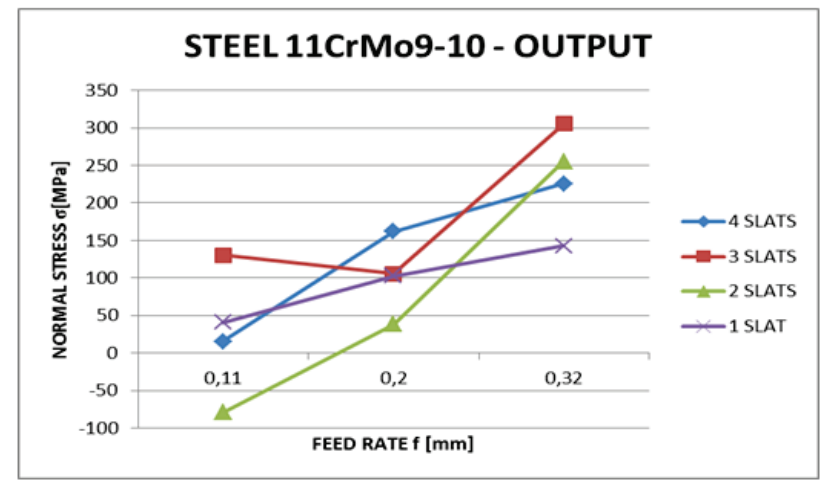

Figure 8 Steel 11CrMo9-10 - OUTPUT

The graph - Fig. 8 illustrates the influence on the feed rate on submit normal stress for steel $11 \mathrm{CrMo} 9-10$ on output. The graph clearly shows that when the feed rate increases the stress increases. The maximum value of the stress was achieved in the condition of the feed rate of 0.32 $\mathrm{mm}$ and three slats in the simulator $305,6 \mathrm{MPa}$. Decrease of the stress is seen in conditions of the irregular interrupted cut - one slat, the feed rate $0.32 \mathrm{~mm}$. The compressive stress is seen for the feed rate $0.11 \mathrm{~mm}$, two clamped slats $(-79.3 \mathrm{MPa})$.

\section{CONCLUSION}

Increasing the compressive and tensile stress value causes a change of material properties, mainly mechanical. 
The value of stress should rise with increased feed rate. The occurrence of this stress can cause the formation and spreading of cracks and corrosion of the material. The aim is to suitably arrange the cutting conditions for optimal distribution of the residual stress in the entire volume of the material, preferably to zero values.

The tensile stress is worse than compressive stress. The tensile stress causes faulty integrity of the component and negatively impacts its safety.

The results of material $\mathrm{C} 45$ confirm that increased feed rate ensures a rise of residual stress. Generally, it is valid that an irregular interrupted cut has an influence on the amount of introduced stress. The measured output stress achieved lower values than the input. The exception was for two slats with a feed rate of $0.32 \mathrm{~mm}$ when the output stress was higher than the input. In the conditions of a regular interrupted cut for the feed rate of $0.11 \mathrm{~mm}$, the value was closed to zero. Compressive stress for the feed rate of $0.11 \mathrm{~mm}$ for both examples, input and output were measured using an irregular interrupted cut.

Material 11CrMo9-10 does not confirm the rule about feed rate. The number of fixed slats has an influence on amount of stress. The highest values of stress were measured for the $0,32 \mathrm{~mm}$ feed rate. Decreasing the number of slats in jig ensures lower values of stress. The lowest value was measured with two slats for $0.2 \mathrm{~mm}$ feed rate - input. The results of the material 11CrMo9-10 showed negative numbers - compressive stress too. In comparison with steel $\mathrm{C} 45$, when the result was the compressive stress for one slat, with steel $11 \mathrm{CrMo} 9-10$ this problem appears with 2 slats, for the lowest feed rate.

\section{Acknowledgement}

This work was supported by the European Regional Development Fund in the IT4 Innovations Centre of Excellence project CZ.1.05/1.1.00/02.0070 and by Education for Competitiveness Operational Programme financed by Structural Founds of Europe Union in project Integrita CZ.1.07/2.3.00/20.0037 and by Student Grant Competitions SP2015/116 and SP2015/129 financed by the Ministry of Education, Youth and Sports and Faculty of Mechanical Engineering VŠB-Technical University of Ostrava.

\section{REFERENCES}

[1] Sadilek, M., Kratochvil, J., Petru, J., Cep, R., Zlamal, T., \& Stancekova, D. (2014). Cutting tool wear monitoring with the use of impedance layers. Tehnicki vjesnik-Technical Gazette, 21(3), 639-644

[2] Petan, L., Ocaña, J., \& Grum, J. (2016). Effects of Laser Shock Peening on the Surface Integrity of $18 \%$ Ni Maraging Steel. Strojniški vestnik - Journal of Mechanical Engineering, 62(5), 291-298. https://doi.org/10.5545/sv-jme.2015.3305

[3] Nieslony, P., Krolczyk, G. M., Zak, K., Maruda, R. W., \& Legutko, S. (2017). Comparative assessment of the mechanical and electromagnetic surfaces of explosively clad Ti-steel plates after drilling process. Precision Engineering, 47, 104-110. https://doi.org/10.1016/j.precisioneng.2016.07.011

[4] Brinksmeier, E., Cammett, J. T., Konig, W., Leskovar, P., Peters, J., \& Tonshoff, H. K. (1982). Residual Stresses Measurement and Causes in Machining Processes. Manufacturing Technology, 31(2), 491-510.
https://doi.org/10.1016/S0007-8506(07)60172-3

[5] Capello, E. (2006). Residual stresses in turning: Part II. Influence of the machined material. Journal of Materials Processing Technology, 172(3), 319-326. https://doi.org/10.1016/j.jmatprotec.2005.10.009

[6] Rossini, N. S., Dassisti, M., Benyounis, K. Y., \& Olabi, A. G. (2012). Methods of measuring residual stresses in components. Materials and Design, 35, 572-588. https://doi.org/10.1016/j.matdes.2011.08.022

[7] Nieslony, P., Cichosz, P., Krolczyk, G. M., Legutko, S., Smyczek, D., \& Kolodziej, M. (2016). Experimental studies of the cutting force and surface morphology of explosively clad Ti-steel plates. Measurement, 78, 129-137. https://doi.org/10.1016/j. Measurement. 2015.10.005

[8] Capello, E. (2005). Residual stresses in turning: Part I. Influence of process parameters. Journal of Material Processing Technology, 160, 221-228. https://doi.org/10.1016/j.jmatprotec.2004.06.012

[9] Patrik, D., Gunnberg, F., \& Jacobson, M. (2004). The Influence of rake angle, cutting feed and cutting depth on residual stresses in hard turning. Journal of Materials Processing Technology, 147, 181-184. https://doi.org/10.1016/j.jmatprotec.2003.12.014

[10] Farshid, J., Amirabadi, H., \& Sadri, J. (2015). Experimental measurement and optimization of tensile residual stress in turning process of Inconel718 superalloy. Measurement, 63, 1-10. https://doi.org/10.1016/j.measurement.2014.11.021

[11] Drbúl, M., Šajgalík, M., Šemcer, J., Czánová, T., Petřkovská, L., \& Čepová, L. (2014). Strojárska metrológia a kvalita povrchov vytvorených technológiami obrábania / Žilina: ŽU v Žilině, $115 \mathrm{p}$.

[12] Krolczyk, G. M., Krolczyk, J. B., Maruda, R. W., Legutko, S., \& Tomaszewski, M. (2016). Metrological Changes in Surface Morphology of High-Strength Steels in Manufacturing Processes. Measurement, 88, 176-185. https://doi.org/10.1016/j.measurement.2016.03.055

[13] Malotová, Š. (2015). Vliv technologických parametrů v závislosti na povrchová napětí při obrábění na simulátoru přerušovače řezu. Diplomová práce / VŠB - TU Ostrava.

[14] Neslusan, M., Mrkvica, I., Cep, R., \& Raos, P. (2012). Heat distribution when nickel alloy grinding. Tehnicki vjesnikTechnical Gazette, 19(4), 947-951.

\section{Contact information:}

Sarka MALOTOVA, MSC

VŠB-Technical University of Ostrava, Faculty of Mechanical Engineering, Department of Machining, Assembly and Engineering Metrology,

17.listopadu 15, 70833 Ostrava, Czech Republic sarka.malotova@vsb.cz

Robert CEP, Assoc. Prof., PhD, MSc

VŠB-Technical University of Ostrava, Faculty of Mechanical Engineering,

Department of Machining, Assembly and Engineering Metrology,

17. listopadu 15, 70833 Ostrava, Czech Republic

robert.cep@vsb.cz

\section{Tomas ZLAMAL, PhD, MSc}

VŠB-Technical University of Ostrava, Faculty of Mechanical Engineering, Department of Machining, Assembly and Engineering Metrology,

17. listopadu 15, 70833 Ostrava, Czech Republic

tomas.zlamal@vsb.cz

Petr MOHYLA, Assoc. Prof., PhD, MSc

Faculty of Mechanical Engineering, Department of Mechanical Technology,

17. listopadu 15, 70833 Ostrava, Czech Republic

petr.mohyla@vsb.cz

Andrej CZÁN, Prof., PhD, MSc

Faculty of Mechanical Engineering, University of Žilina,

Univerzitna 1, 010 26, Zilina, Slovakia

andrej.czan@fstroj.uniza.sk 
Aco ANTIĆ, Assoc. Prof.

Faculty of Technical Sciences, University of Novi Sad,

Trg Dositeja Obradovića 6 ,

21000 Novi Sad, Republic of Serbia

antica@uns.ac.rs

Igor BUDAK, Assoc. Prof.

Faculty of Technical Sciences, University of Novi Sad,

Trg Dositeja Obradovića 6,

21000 Novi Sad, Republic of Serbia

budaki@uns.ac.rs

\section{Lobonţiu MIRCEA}

Faculty of Mechanical Engineering,

Universitatea Tehnicá din Cluj - Napoca,

B-dul Muncii nr. 103-105,

400641, Cluj-Napoca, România

mircea.lobontiu@ubm.ro 